\title{
Advancements in recombinant technology for production of butyrylcholinesterase, a bioscavenger of nerve agents
}

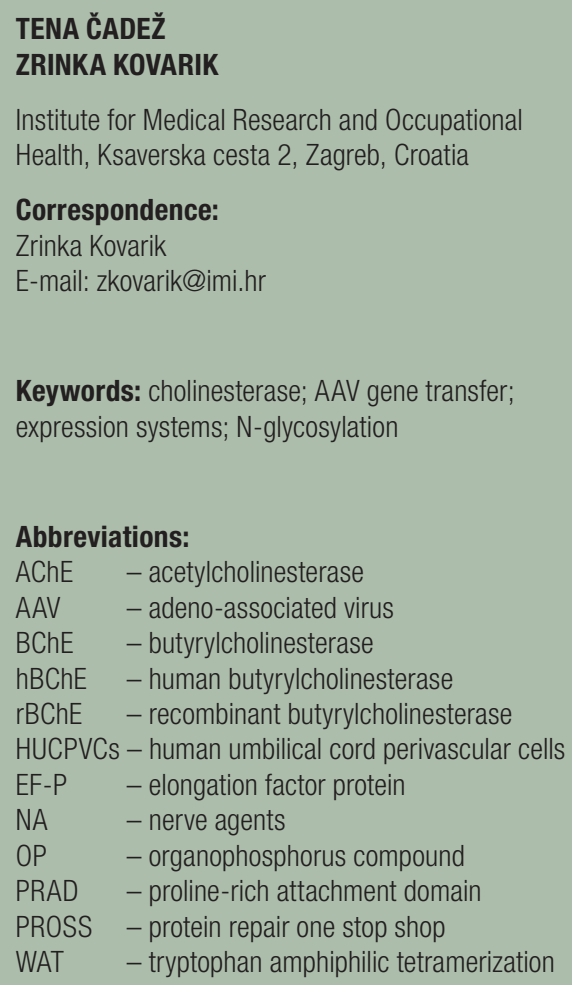

\begin{abstract}
Butyrylcholinesterase (BChE) is a serine hydrolase present in plasma and other mammalian tissues. As a target of organophosphorous pesticides and warfare nerve agents, $\mathrm{BChE}$ acts as their stoichiometric bioscavenger. However, so far it has been a significant challenge to produce $\mathrm{BChE}$ at large scales and low cost. For decades, numerous research efforts have been directed first at isolation from human volunteers and later at production of BChE in eukaryotic and prokaryotic expression systems. In this review we focused on recent studies on recombinant $\mathrm{BChE}$ discussing reasons why the efficient, economically sensible expression system for recombinant $\mathrm{BChE}$ is hard to develop. We also bring the most recent advancements in the use of expression of human $\mathrm{BChE}$ in vivo as an effective prophylactic against organophosphate poisoning.
\end{abstract}

\section{INTRODUCTION}

7 he widespread use of organophosphorus compounds (OPs), primarily pesticides, but also the availability of highly toxic nerve agents (NA), generates a significant number of poisonings worldwide; leading up to several hundred thousands of deaths per year (1). From the moment of their synthesis, organophosphorus compounds have become a constant threat throughout history and have maintained their presence to this day. Taking that into consideration, countermeasures for OP poisoning should pursue the same pattern or even be one step ahead. Standardized care in cases of NA poisoning with sarin (GB), soman $(\mathrm{GD})$, tabun (GA) and VX is based on a combination of anti-muscarinic antagonist atropine, reactivators of NA-inhibited acetylcholinesterase (AChE, EC 3.1.1.7), and an anticonvulsant (2). Although conventional nerve agent countermeasures have effects on survival rates depending on the time of application, shortcomings in the prevention of central nervous system exposure are commonly observed as convulsions or brain damage (3). Pre-treatment with bioscavangers, enzymes that rapidly bind OPs and reduce their free levels in circulation can prevent long term health effects in the central nervous system imposed by OP-inhibition of the synaptic AChE. For enzymes to be used as bioscavengers they should act rapidly and against a broad spectrum of NAs, have prolonged circulation time (ideally more than 10 days), have no immunogenic or toxic properties, be available at sufficient concentration and at reasonable cost $(4-6)$. 
The most investigated bioscavenger is human plasma butyrylcholinesterase (BChE, EC 3.1.1.8), serine hydrolase and enzyme analogue of AChE. Although its physiological function is not essential as that of $\mathrm{AChE}$, it seems that it plays a back-up role in maintaining and regulating the cholinergic activity (7). Also it has been shown that $\mathrm{BChE}$ is involved in metabolism of drugs including cocaine, heroin and aspirin $(8-10)$ as well as in physiological pathways of ghrelin, the appetite-promoting hormone which indicate its possible role in lipid metabolism $(11,12)$.

Given the pharmaceutical importance of BChE, the goal is to find a way to produce BChE in large quantities. Human population has a wide range of plasma $\mathrm{BChE}$ concentration from 3.5 to $9.3 \mathrm{mg} / \mathrm{L}(7,13)$. Isolation of $\mathrm{hBChE}$ from obsolete plasma or Cohn fraction IV-4 is possible on a laboratory and industrial scale using ion exchange chromatography at $\mathrm{pH} 4$ and affinity chromatography on procainamide-Sepharose or Hupresin to obtain purified plasma hBChE from $100 \mathrm{~L}$ in single cycle $(14,15)$. Outdated human plasma is a reliable source for the hBChE tetramer which is important for long half-life and bioscavenging activity, but production is expensive and time-consuming, since isolation requires large amounts of human plasma to achieve low levels of purified hBChE (13). An alternative method for obtaining large amounts of $\mathrm{BChE}$ is via synthesis of recombinant proteins in different expression systems. However, hBChE has proven difficult to reproduce by recombinant technology because it's hard to accomplish fully active tetrameric form. Problem with most of recombinant expression systems is based on inadequate glycosylation, and deficient oligomerization of expressed BChE. In the majority of expression systems recombinant $\mathrm{BChE}$ are found as monomers or dimers which lead to low half-time in circulation and unsatisfactory pharmacologic properties (16,
17). Considerable effort has been embedded into developing transgenic recombinant platforms to synthesize fully functional recombinant $\mathrm{hBChE}$ cost-effectively and on a large scale, and this task is still under way.

\section{THE IMPORTANCE OF STRUCTURE FOR FUNCTIONAL BCHE}

$\mathrm{hBChE}$ is a glycoprotein formed from four identical subunits encoded with gene localized on chromosome 3 (3q26) (18). Each monomeric subunit has a molecular weight of $85 \mathrm{kDa}$ consisting of 574 amino acid residues, $24 \%$ of weight is consistent with 9 polysaccharide chains $N$-linked with asparagine residues of protein. hBChE is present in several oligomeric forms, of which the tetrameric form in the serum is most abundant, and the remaining is represented by trimeric, dimeric and monomeric forms (7). Each monomeric hBChE subunit contains a catalytic triad (Ser198, His438, and Glu325) within a $20 \AA$ deep active site gorge. Two domains differ in native hBChE structure, the core or catalytic domain (amino acids 1-529) and the tetramerization domain (amino acids 530-574). The tetramerization domain of $\mathrm{hBChE}$ is formed by C-terminal tryptophan amphiphilic tetramerization (WAT) helices from each subunit as a superhelical assembly around a central polyproline (19). The WAT domain can connect with the proline-rich attachment domain (PRAD) sequence of ColQ or PRIMA protein anchors that enable cohesion of $\mathrm{BChE}$ to the synaptic membranes of nervous system (20). Polyproline-rich peptides associated with $\mathrm{BChE}$ are mostly derived from lamelliopodin ( $70 \%)$, membrane-associated protein (21, 22). PRAD sequence in WAT/PRAD complex adopts a polyproline II helical conformation and runs antiparallel. This complex is important to mediate the congregation of
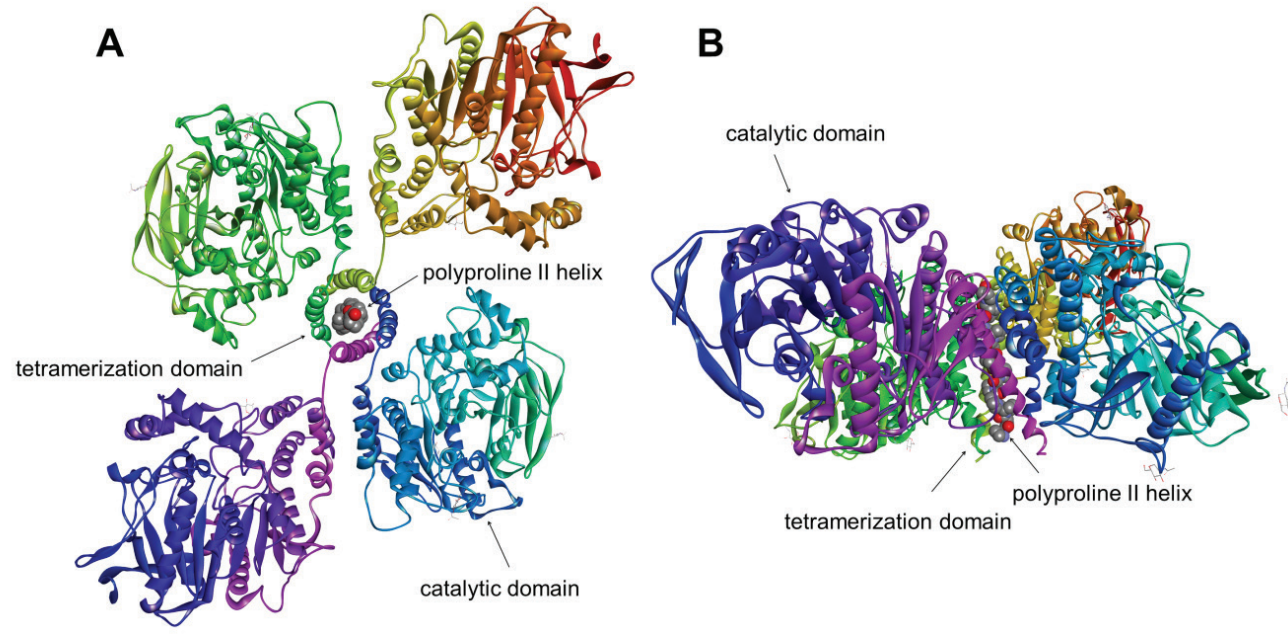

tramerization domain

Figure 1. Cryo-EM structure of the native BChE tetramer (PDB 612T). A) Top view of the BChE tetramer as dimer of dimers in which the monomers are diagonally equivalent with polyproline II helix in the centre. B) Side view of the BChE tetramer with tetramerization domain concealed between dimers. 
tetrameric native $\mathrm{hBChE}$ which displays effective therapeutic action in the presence of OP compounds or other drugs like cocaine $(19,23-26)$.

The crystal structure for recombinant $\mathrm{hBChE}$ monomer (PDB 1P0I) was solved with truncation at C-terminus of 40 amino acid residues in the tetramerization domain (27). Crystal structure of full-length glycosylated tetrameric $h B C h E$ by X-ray crystallography has not been determined so far, but alternative method emerged. Cryogenic electron microscopy provided 3D structure of hBChE (Figure 1) using crystal structure for recombinant hBChE with all the N-glycosylated sites presents (PDB 4AQD) and WAT helices based on the synthetic WAT/ PRAD complex of AChE (PDB 1VZJ) $(28,29)$. The cryoEM structure of tetramer hBChE (PDB 6I2T; EMD0256) is a dimer of dimers stabilized by a superhelical assembly which could be the key to future advancements in recombinant technology for BChE production. The obtained model showed catalytic domains within dimers asymmetrically linked to the WAT/PRAD complex inducing concealment of the tetramerization domain between catalytic units which can contribute to the stability of the tetrameric form of $\mathrm{hBChE}(30,31)$.

An important role in the stabilization of the tetrameric structure can also be the contribution of a high glycosylation level of $\mathrm{BChE}$ which in past studies was assumed as an impairment to get proper hamper of crystals but a model obtained with a combination of cryo-EM, smallangle X-ray scattering and molecular dynamics simulations allowed us new insights. The acquired model clearly shows that some glycans interact between monomers of bordering dimers. These glycans are linked to asparagine 241 of one monomer and asparagine 256 of the adjoin monomer thus strengthening the tetramer stability in addition to the C-terminal knot (31). Post-translation modification as $N$-glycosylation except for tetramer stability of BChE can also contribute to immunocompatibility, reactivity and pharmacokinetic stability of enzyme in circulation (32). Except for glycosylation for obtaining longer half-life in circulation, high importance is given to inter monomeric disulfide bonds and sialylation for prevention of binding $\mathrm{BChE}$-glycans to the asialoglycoprotein receptor in liver $(33,34)$.

Accumulation of $\mathrm{BChE}$ in aggregates was promoted by organophosphorus pesticide, chlorpyrifos oxon ethyl, that induces crosslinking by isopeptide bond leading to dimer, trimer, and higher complexes of BChE (35). The most well-defined isopeptide crosslink between monomers was lysine 544 to glutamic acid 542 located in the $\mathrm{C}$-terminus tetramerization domain. It is worthy to mention that the protein aggregates are a characteristic feature of neurodegenerative diseases such as Parkinson's and Alzheimer's, and OP-induced crosslinking of proteins might be a link between pesticide exposure and the development of some cases of Alzheimer's and Parkinson's diseases (35).

\section{HUMAN BCHE AS A BIOSCAVENGER OF NERVE AGENTS}

$\mathrm{hBChE}$ was selected as the most promising bioscavanger candidate for further development in 2007 when it acquired research status for a new drug from the US Food and Drug Administration. Bioscavangers as, in this case, OP-reacting proteins, must meet certain standards which account for no behavioural and physiological side effects and also protection higher than $5 \mathrm{LD}_{50}$ of more than one nerve agent. $\mathrm{hBChE}$ rapidly binds nerve agents and having high half-time in circulation of $12-15$ days can provide extended protection of the synaptic $\mathrm{AChE}$ against nerve agents while avoiding unwanted immunological responses $(2,4)$. BChE can be defined as a stoichiometric bioscavanger, meaning that it has covalent interactions with OP compounds in a 1:1 ratio, i.e. one molecule of $\mathrm{BChE}$ can only remove one molecule of OP in blood. In this way, the concentration of the OP compound in the bloodstream is lowered, but the enzyme remains practically permanently inhibited. Therefore, although stoichiometric bioscavengers are very effective, they must be applied at a high concentration for the OP compound to be removed within a single circulation period (4). A hBChE dose of $2400 \mathrm{nM}$ which corresponds to $200 \mathrm{mg}$ per $70 \mathrm{~kg}$ is a prophylactic in case of human exposure to a dose of $2-5 \mathrm{LD}_{50}$ nerve agents $(5,36)$. Animal studies have shown that administration of a higher dose of $\mathrm{hBChE}$ would provide protection from exposure to $5.5 \mathrm{LD}_{50} \mathrm{GD}$ and $8 \mathrm{LD}_{50} \mathrm{VX}$ (26). Higher doses can easily trigger an immune response but testing on mice with a 800 -times higher dose than in their system has shown no unwanted effects on health. Moreover, intravenously or intramuscularly applied plasma-derived $\mathrm{hBChE}$ was regarded as safe in phase I clinical trials $(4,13)$.

The use of $\mathrm{hBChE}$ as a stoichiometric scavenger requires a high concentration of named enzyme which is hard to come by, so the feasibility of other approaches was explored. Catalytic systems combined of bioscavangers as $\mathrm{BChE}$ and reactivators as oximes seemed like a possible solution considering that they can neutralize substantial amounts of OP molecules by cycles of inhibition and reactivation, making requirements for $\mathrm{BChE}$ concentrations lower. This pseudo-catalytic system is limited by the effectiveness of reactivators to induce dephosphylation of the enzyme active serine. Unfortunately, standard reactivators such as 2-PAM, HI-6 and obidoxime are mainly intended for the reactivation of $\mathrm{AChE}$ and the reactivation of $\mathrm{BChE-OP}$ conjugates by these compounds is inefficient (37). In the last decade, interest in the design of $\mathrm{BChE}$ reactivation-specific oximes has emerged so groups like quaternary benzaldoximes (38), imidazolium and benzimidazolium oximes (39), chlorinated pyridinium oximes (40) are appearing and opening ground for future research in pseudo-catalytic BChE-based systems, which remains relevant. 


\section{EXPRESSION OF RECOMBINANT BCHE IN PROKARYOTIC SYSTEMS}

Prokaryotic cells in terms of technology are the simplest and most economically acceptable system for producing recombinant proteins. Nevertheless, attempts to express native BChE in Escherichia coli have so far been unsuccessful. One of the reasons was presence of three inter monomeric disulfide bonds unable to form in $E$. coli causing accumulation of partially folded BChE as inclusion bodies (7). Ongoing problem with this expression system is also related to the prokaryotic inability of posttranslational modifications of mammalian proteins i.e., E. coli does not have its own glycosylation system. Camylobacter jejuni has a developed $N$-glycosylation system due to the enzymatic cascade of alkaline polygalacturonate lyase, and glycosyltransferase. The transfer of this system to the genetically known bacterium $E$. coli would allow production of recombinant glycoproteins that makes $2 / 3$ of eukaryotic proteins. However, for the time being, this mechanism can only be used for glycosylation of $C$. jejuni proteins because bacterial $N$-glycans are completely distinct from any known eukaryotic glycan. Challenges facing this post modification can possibly be overthrown by the availability of needed glycan precursors by design gene knockout strains that overproduce glycan precursors (41-43).

As stated before, glycosylated $\mathrm{BChE}$ is interesting from a pharmacological point of view as a tetramer, because of its longer retention capacity and its better pharmacokinetic profile than a dimer or monomer. Tetrameric BChE in prokaryotes is difficult to obtain also due to the lack of proline-rich peptides that, interacting with the C-terminal BChE domain, promote oligomerization. The prolinerich sequences in prokaryotic expression are omitted since such amino acid sequence slow down the translation of natural and modified gene expression. The polyproline mRNA motif causes the ribosome to slow down, thereby reducing the efficiency of translocation, the role of which, although not fully elucidated, is associated with gaining time for co-translational formation and membrane insertion. To reduce ribosome retention, prokaryotic cells use an EF-P (elongation factor protein) that enters the empty E site into the ribosome and binds close to the peptidyltRNA. EF-P contains a lysine residue modified by the enzymes YjeK and YjeA allowing the $\beta$-lysyl moiety on Lys34 reach the active site of a ribosome and restore catalytic activity. EF-P is found in less than 100 E. coli proteins, which describes a small number of enzymes containing polyproline motifs in prokaryotes (44-46). For the introduction of polyproline in the prokaryotic expression system, it is necessary to develop a system for the co-expression of EF-P or use an E. coli species with an already existing peptide (47).

Recently, Goldenzweig et al. (48) reported a computational method based on the structure and sequence for the design of stable proteins for prokaryotic expression, Protein Repair One Stop Shop (PROSS). After successful expression of human $\mathrm{AChE}$ in the bacterial system, the same possibility arose for BChE. The PROSS system uses two filters that consider each mutation individually, limiting the design of the protein to mutations that could further contribute to the stability of the structure. Excluding context-dependent mutations leads to the minimization of false positives risk, i.e. structures that are stable in silico but unstable in vivo (48). The PROSS system proposed 7 variants of $\mathrm{BChE}$ that were expressed in E. coli strain as a fusion protein of thioredoxin with preserved amino acid residues of the catalytic triad and gorge of the active site to allow safe substrate binding. Surface residue optimization and protein stabilization suggested by the PROSS algorithm allowed isolation of active BChE, which was then purified to homogeneity. The purified rBChE of prokaryotic expression contains 47 intentional mutations with intact active gorge granting it similar kinetic activity as of $\mathrm{rBChE}$ produced in chinese hamster ovaries $(\mathrm{CHO})$ cells or plasma derived hBChE $(49,50)$. As post-translational $N$-glycosylation and presence of polyproline peptides were excluded from prokaryotic BChE expression, it was essential to preserve amino acid residues during PROSS analysis that maintain the homodimeric structure of the protein. The isolated protein according to SEC-MAL analysis behaves as a monomer $(70 \mathrm{kDa})$ despite the conservation of residues included in the dimer interface. The presence of two mutations in the immediate vicinity of the last helix, Gln518His and Thr523Asn, are the suspected reason for impairment of dimer formation. However, the crystal structure reveals a dimeric form surely driven by a higher local protein concentration (51). The homodimer is connected by a bundle of four helices, each monomer joined by a single pair of spirals forming canonical dimer observed before (28). The main difference in structure between human BChE expressed in $E$. coli and in eukaryotic expression system is recognized as a Cys65-Cys92 disulfide bond. It has been established based on the amino acid residue occupancy that there has been a partial breakdown of the linkage between the chains (51). An additional E377C/A516C mutation to the prior BChE mutant provided a crosssubunit disulfide bond featuring a full dimeric form with unaffected catalytic activity in comparison to BChE without the additional mutation. BChE with 48 mutations has shown improved termostability justifying that disulfide bonds are important for dimerization and stability of BChE (52).

Previously it was not possible to express proteins that contain disulfide bonds in prokaryotes because of an unfavorable reduction environment in bacterial cytoplasm (53). E. coli $\mathrm{SHuffle}^{\circledast}$ strains based on $\operatorname{tr} x B$ suppression have enhanced capacity to correctly fold proteins with multiple disulfide bonds in the cytoplasm. SHuffle strains also contain constitutively expressed, cytoplasmic, 
disulfide bond isomerase to aid in the formation of disulfide bonds and promote proper protein folding $(54,55)$. The ability to form wanted inter monomeric disulfide bonds impedes misfolding and generation of unfunctional proteins into the inclusion body. This is evident from two disulfide bonds fully formed Cys252-Cys263; Cys400-Cys519 in prokaryotic BChE without palpable denaturation and no major differences in structure of recombinant BChE. It is important to emphasize that by optimizing surface residues and stabilizing proteins, it was possible to isolate and purify homogeneous, active butyrylcholinesterase thanks to the PROSS algorithm $(51,56)$. Further research to improve glycosylation process and additional expression of the polyproline peptide prokaryotic expression system could be the answer for the production of the therapeutic butyrylcholinesterase protein.

\section{EXPRESSION OF RECOMBINANT BCHE IN EUKARYOTIC SYSTEMS}

Expression of $\mathrm{rBChE}$ in eukaryotic cells has been yielded with reliable activity in different mammalian cells as CHO, HEK293, COS-7 counting production up to 5 $\mathrm{mg} / \mathrm{L}$. Technical means such as spinner, roller bottles or bioreactors help with the higher production of wanted enzymes, which for BChE should be at least 50-100 mg/l to hold as an affordable expression system $(5,13,16)$. Large scale expression of $\mathrm{BChE}$ is often followed by an increase of protein misfolding due to the overload of posttranslation modification in eukaryotic cells leading to production of a certain amount of inactive protein. The development of a system with adequate co-expression of peptides or enzymes included in post-translation adjustments can help avert decreases in specific BChE activity. The co-expression of the PRAD peptide during BChE expression in the eukaryotic system or the addition of chemically synthesized polyproline to the growth medium can increase tetramer production by $70 \%(23,57)$. Transfection of expression vectors containing EF-1 promoter with proline-rich chaperons in $\mathrm{CHO}$ cells can increase production of active $\mathrm{rBChE}$ to $40 \mathrm{mg} / \mathrm{L}(16,58)$. $\mathrm{BChE}$ expressed in $\mathrm{CHO}$ cells showed longer retention times but still not as long as plasma-derived BChE (5759). Regardless of improvements, mammalian cells as an expression system of $\mathrm{BChE}$ are still economically undesirable.

Recombinant BChE was also successfully expressed in the silkworm (60) Nicotiana benthamiana (61), rice (62), and insect cells (28) with proper enzymatic activity but poor yield. In cases of enzymes from silkworms and transgene plants, incomplete or improper glycosylation occurs which can cause instability of $\mathrm{rBChE}$. Even though there is a possibility to isolate tetrameric plant-derived $\mathrm{rBChE}$ (63), nonhuman glycan structure presents the issue of being recognized as an immunogen. Also, there is need of co-expression for sialylation which has a significant role in the pharmacokinetic behavior of a $\mathrm{BChE}$ in vivo (34, 64). An industrial production of $\mathrm{rBChE}$ from milk of transgenic goats allows a high amount of fully active $\mathrm{rBChE}$ (up to $5 \mathrm{~g} / \mathrm{L}$ ) that is low-glycosylated mostly monomers or dimers. It has been shown that the PEGylation of $\mathrm{rBChE}$ prolonged its half-life in blood stream to $40-45$ hours in pigs (65). Whereas $\mathrm{rBChE}$ derived from milk of transgenic mice had better pharmacokinetic properties even without PEGylation $\left(t_{1 / 2}=32 \mathrm{~h}\right.$ in pigs), the production yield was low (in $\mu \mathrm{g} / \mathrm{L}$ ) (66). Except for PEGylation as a tool to improve circulation half-life of monomers or dimers expressed in milk but also in silkworms, transgenic plants, etc., the solution could be nanocapsules. Encapsulating $\mathrm{BChE}$ in zwitterionic polymer gel layer can protect it from denaturation and improve pharmacokinetic properties of rBChE (67). For now, PEGylated BChE from the milk of transgenic goat is implemented as prophylaxis or treatment in case of OP use until a better source emerges (65).

A novel source of therapeutic BChE was recently investigated where a fully functioning tetrameric enzyme was produced without the need for modifications by other systems. Mesenchymal stromal cells isolated form Wharton's Jelly of umbilical cord known as human umbilical cord perivascular cells (HUCPVCs) are the key for this therapeutic platform (68). This expression system is suitable for producing native $\mathrm{BChE}$ but not in high amounts. The paradigm that HUCPVCs has cellular machinery that protects and synthetizes genetic material of $\mathrm{BChE}$ with continuous emission in circulation can be used to increase enzyme output with transgene encoding of $\mathrm{hBChE}$ controlled by a proper promotor. To take full use of this system for $\mathrm{BChE}$ expression there is need to disable the internal regulatory system of HUPCVCs that inhibit accumulation of $\mathrm{BChE}$ in the extracellular matrix (68). The expression system provided by HUCPVCs could be a future answer for in vivo delivery of BChE, minimizing the necessity for reiterative dosing.

\section{VIRUS-MEDIATED EXPRESSION OF BCHE}

The in vivo delivery system was previously investigated as a persistent source of stoichometric bioscavenger $\mathrm{BChE}$ to uphold sufficient levels essential for OP neutralization. Direct delivery to system would surely reduce the cost and protein loss with bypassing enzyme purification. Adenovirus-mediated delivery of $\mathrm{hBChE}$ to organs as liver or muscle that are capable to express functional hBChE has shown efficacy with increased production more than 300 fold over the baseline in mice. Even though the concentration of hBChE showed protection up to $5 \mathrm{LD}_{50}$ of VX in mice, it was not long lasting ( -10 days) due to adenovirus immunogenicity (69-71). An alternative strategy arose with adeno-associated virus vectors (AAV) to produce $\mathrm{hBChE}$ after it was regarded as safe (72). The AAV vector used in bicistronic form to co-express $\mathrm{hBChE}$ and poly- 
prolin peptide facilitate the formation of fully functional tetramers. The administration of AAV-hBChE vectors with intra muscular injection provided expression of hBChE within 3-4 weeks in mice similar as in studies with intravenous injection for delivery of $\mathrm{AVV}$ vectors to the liver. From the liver, expressed enzyme levels were sustained for 8-16 months, but from muscles after single injection expression lasted without silencing up to 140 days (73-75). Levels of expression achieved through 2-3 weeks were sufficient to neutralize $2 \mathrm{LD}_{50}$ VX. Taking into consideration the correlation of inter muscular dose of $10^{12}$ genome copies per mouse and $0.5 \mathrm{mg} / \mathrm{ml}$ of active $\mathrm{hBChE}$ in serum, prophylactic efficiency can be adjusted by vector dose (75). The results obtained so far are encouraging for further studies on non-human primates to ascertain the AVV-mediated delivery efficiency and impact on the immunosystem with higher doses.

Recently Gao et al. (76) showed that the AAV gene transfer of $\mathrm{BChE}$ could impact $\mathrm{BChE}$ expression across the entire brain or in selective regions of the central nervous system. Their approach was focused on the $\mathrm{BChE}$ gene transfer as a means to explore the emerging issue of the enzyme's physiologic role as a key regulator of ghrelin in general and, more particularly, in specific brain centers involved in emotional states that are strongly influenced by this peptide hormone (76).

\section{CONCLUSION}

Butyrylcholinesterase, even though without any essential function in the organism, has shown great importance as a bioscavenger for cholinergic systems in cases of $\mathrm{OP}$ exposure. One drawback to bioscavenger-based therapy is the need for sustained delivery of large enzyme quantities - an expensive process. To alleviate this problem, recombinant technology, expression system and more recently gene therapy made a major breakthrough in pursuance of economic goals, requirements for post-modification and also to gain long-term systematic expression of fully functional hBChE in efficacious levels. In regard with expression system, gene therapy could also show potential in unresolved issues of BChE's physiological roles or its role in the onset and progression of Alzheimer's disease.

Acknowledgements: We thank Dr Goran Šinko for preparing the figure, and Makso Herman for language editing. This study was supported by the Croatian Science Foundation (IP-2018-01-7683).

\section{REFERENCES}

1. KWONG TC 2002 Organophosphate pesticides: Biochemistry and clinical toxicology. Ther Drug Monit 24(1):144-149.

https://doi.org/10.1097/00007691-200202000-00022
2. LUKEY BJ, ROMANO JAJ, SALEM H 2007 Chemical Warfare Agents: Chemistry, Pharmacology, Toxicology, and Therapeutics, Second Edition, CRC Press, Boca Roton

3. JOHN H, BALSZUWEIT F, KEHE K, WOREK F, THIERMANN H 2015 Toxicokinetic aspects of nerve agents and vesicants, In: Gupta R (ed) Handbook of Toxicology of Chemical Warfare Agents, Elsevier, Academic Press/Elsevier, Amsterdam, p 817-856. https://doi.org/10.1016/B978-0-12-800159-2.00056-7

4. DOCTOR BP, SAXENA A 2005 Bioscavengers for the protection of humans against organophosphate toxicity. Chem Biol Interact 157-158: 167-171. https://doi.org/10.1016/j.cbi.2005.10.024

5. LENZ DE, YEUNG D, SMITH JR, SWEENEY RE, LUMLEY LA, CERASOLI DM 2007 Stoichiometric and catalytic scavengers as protection against nerve agent toxicity: a mini review. Toxicology 233(1-3): 31-39. https://doi.org/10.1016/j.tox.2006.11.066

6. MASSON P, NACHON F 2017 Cholinesterase reactivators and bioscavengers for pre- and post-exposure treatments of organophosphorus poisoning. J Neurochem 142(Suppl 2):26-40. https://doi.org/10.1111/jnc.14026

7. MASSON P, CARLETTI E, NACHON F 2009 Structure, activities and biomedical applications of human butyrylcholinesterase. Protein Pept Lett 16(10): 1215-1224. https://doi.org/10.2174/092986609789071207

8. GIACOBINI E 2003 Butyrylcholinesterase: its role in brain function. In: Giacobini E (ed) Butyrylcholinesterase, Its Function and Inhibitors. Martin Dunitz Ltd, London, p 1-20.

9. KOVARIK Z, SIMEON-RUDOLF V 2004 Interaction of human butyrylcholinesterase variants with bambuterol and terbutaline. J Enzyme Inhib Med Chem 19: 113-7.

https://doi.org/10.1080/14756360410001667300.

10. BOSAK A, GAZIĆ SMILOVIĆ I, ŠINKO G, VINKOVIĆ V, KOVARIK Z 2012 Metaproterenol, isoproterenol, and their bisdimethylcarbamate derivatives as human cholinesterase inhibitors. J Med Chem 55: 6716-23. https://doi.org/10.1021/jm300289k.

11. BRIMIJOIN S, CHEN VP, PANG YP, GENG L, GAO Y 2016 Physiological roles for butyrylcholinesterase: A BChE-ghrelin axis. Chem Biol Interact 259: 271-275. https://doi.org/10.1016/j.cbi.2016.02.013

12. CHEN VP, GAO Y, GENG L, BRIMIJOIN S 2017 Butyrylcholinesterase regulates central ghrelin signaling and has an impact on food intake and glucose homeostasis. Int J Obes 41(9): 1413-1419. https://doi.org/10.1038/ijo.2017.123

13. LOCKRIDGE O 2015 Review of human butyrylcholinesterase structure, function, genetic variants, history of use in the clinic, and potential therapeutic uses. Pharmacol Ther 148:34-46. http://dx.doi.org/10.1016/j.pharmthera.2014.11.011

14. LOCKRIDGE O, SCHOPFER LM, WINGER G, WOODS JH 2005 Large scale purification of butyrylcholinesterase from human plasma suitable for injection into monkeys; a potential new therapeutic for protection against cocaine and nerve agent toxicity. J Med Chem Biol Radiol Def 3:nihms5095. https://doi.org/10.1901/jaba.2005.3-nihms5095

15. SCHOPFER LM, LOCKRIDGE O, DAVID E, HINRICHS SH 2019 Purification of human butyrylcholinesterase from frozen Cohn fraction IV-4 by ion exchange and Hupresin affinity chromatography. PLoS One 14(1): 1-24. https://doi.org/10.1371/journal.pone.0209795

16. ILYUSHIN DG, HAERTLEY OM, BOBIK TV, SHAMBORANT OG, SURINA EA, KNORRE VD, MASSON P, SMIRNOV IV, GABIBOV AG, PONOMARENKO NA 2013 Recombinant human butyrylcholinesterase as a new-age bioscavenger drug: development of the expression system. Acta Naturae 5(1): 73-84 https://doi.org/10.32607/20758251-2013-5-1-73-84

17. KOLARICH D, WEBER A, PABST M, STADLMANN J, TESCHNER W, EHRLICH H, SCHWARZ HP, ALTMANN F 2008 
Glycoproteomic characterization of butyrylcholinesterase from human plasma. Proteomics 8(2): 254-263.

https://doi.org/10.1002/pmic.200700720

18. ALLDERDICE PW, GARDNER HAR, GALUTIRA D, LOCKRIDGE O, LADU BN, MCALPINE P J 1991 The cloned butyrylcholinesterase (BCHE) gene maps to a single chromosome site, 3q26. Genomics 11(2): 452-454. https://doi.org/10.1016/0888-7543(91)90154-7

19. BERNARDI A, KIRSCHNER KN, FALLER R 2017 Structural analysis of human glycoprotein butyrylcholinesterase using atomistic molecular dynamics: the importance of glycosylation site ASN241. PLoS One 12(11): 1-17. https://doi.org/10.1371/journal.pone.0187994

20. BON S, COUSSEN F, MASSOULIÉ J 1997 Quaternary associations of acetylcholinesterase. II. The polyproline attachment domain of the collagen tail. J Biol Chem 272(5): 3016-3021 https://doi.org/10.1074/jbc.272.5.3016

21. LI H, SCHOPFER LM, MASSON P, LOCKRIDGE O 2008 Lamellipodin proline rich peptides associated with native plasma butyrylcholinesterase tetramers. Biochem J 411(2): 425-432. https://doi.org/10.1042/BJ20071551

22. PENG H, SCHOPFER LM, LOCKRIDGE O 2016 Origin of polyproline-rich peptides in human butyrylcholinesterase tetramers. Chem Biol Interact 259: 63-69. https://doi.org/10.1016/j.cbi.2016.02.007

23. ALTAMIRANO CV, LOCKRIDGE O 1999 Association of tetramers of human butyrylcholinesterase is mediated by conserved aromatic residues of the carboxy terminus. Chem Biol Interact 119120: 53-60. https://doi.org/10.1016/S0009-2797(99)00013-7

24. BLONG RM, BEDOWS E, LOCKRIDGE O 1997 Tetramerization domain of human butyrylcholinesterase is at the C-terminus. Biochem J 327(3): 747-757. https://doi.org/10.1042/bj3270747

25. ASOJO OA, NGAMELUE MN, HOMMA K, LOCKRIDGE O 2011 Cocrystallization studies of full-length recombinant butyrylcholinesterase (BChE) with cocaine. Acta Crystallogr Sect F Struct Biol Cryst Commun 67(4): 434-437. https://doi.org/10.1107/S1744309111004805

26. REED BA, SABOURIN CL, LENZ DE 2017 Human butyrylcholinesterase efficacy against nerve agent exposure. J Biochem Mol Toxicol 31:e21886. https://doi.org/10.1002/jbt.21886

27. NICOLET Y, LOCKRIDGE O, MASSON P, FONTECILLACAMPS JC, NACHON F 2003 Crystal structure of human butyrylcholinesterase and of its complexes with substrate and products. J Biol Chem 278(42): 41141-41147. https://doi.org/10.1074/jbc.M210241200

28. BRAZZOLOTTO X, WANDHAMMER M, RONCO C, TROVASLET M, JEAN L, LOCKRIDGE O, RENARD PY, NACHON F 2012 Human butyrylcholinesterase produced in insect cells: huprine-based affinity purification and crystal structure. FEBS J 279(16): 2905-2916. https://doi.org/10.1111/j.1742-4658.2012.08672.x

29. DVIR H, HAREL M, BON S, LIU WQ, VIDAL M, GARBAY C, SUSSMAN JL, MASSOULIÉ J, SILMAN I 2004 The synaptic acetylcholinesterase tetramer assembles around a polyproline II helix. EMBO J 23(22): 4394-4405.

https://doi.org/10.1038/sj.emboj.7600425

30. LEUNG MR, VAN BEZOUWEN LS, SCHOPFER LM, SUSSMAN JL, SILMAN I, LOCKRIDGE O, ZEEV-BEN-MORDEHAI T 2018 Cryo-EM structure of the native butyrylcholinesterase tetramer reveals a dimer of dimers stabilized by a superhelical assembly. Proc Natl Acad Sci USA 115(52): 13270-13275. https://doi.org/10.1073/pnas.1817009115

31. BOYKO KM, BAYMUKHAMETOV TN, CHESNOKOV YM, HONS M, LUSHCHEKINA SV, KONAREV PV, LIPKIN AV, VASILIEV AL, MASSON P, POPOV VO, KOVALCHUK MV
2019 3D structure of the natural tetrameric form of human butyrylcholinesterase as revealed by cryoEM, SAXS and MD. Biochimie 156:196-205. https://doi.org/10.1016/j.biochi.2018.10.017

32. SOLÁ RJ, RODRÍGUEZ-MARTÍNEZ JA, GRIEBENOW K 2007 Modulation of protein biophysical properties by chemical glycosylation: biochemical insights and biomedical implications. Cell Mol Life Sci 64(16): 2133-2152. https://doi.org/10.1007/s00018-007-6551-y

33. LOCKRIDGE O, ECKERSON HW, LADU B 1979 Interchain disulfide bonds and subunit organization in human serum cholinesterase. J Biol Chem 254(17):8324-8330.

34. CHUNG CY, WANG Q, YANG S, CHOUGH S, SEO Y, CIPOLLO JF, BALTHASAR JP, BETENBAUGH MJ 2020 The impact of sialylation linkage-type on the pharmacokinetics of recombinant butyrylcholinesterases. Biotechnol Bioeng 117(1):157166. https://doi.org/10.1002/bit.27174

35. BIBEROGLU K, TACAL O, SCHOPFER LM, LOCKRIDGE O 2020 Chlorpyrifos oxon-induced isopeptide bond formation in human butyrylcholinesterase. Molecules 25:533.

https://doi.org/10.3390/molecules25030533

36. ASHANI Y, PISTINNER S 2004 Estimation of the upper limit of human butyrylcholinesterase dose required for protection against organophosphates toxicity: a mathematically based toxicokinetic model. Toxicol Sci 77(2):358-367. https://doi.org/10.1093/toxsci/kfh012

37. AURBEK N, THIERMANN H, EYER F, EYER P, WOREK F 2009 Suitability of human butyrylcholinesterase as therapeutic marker and pseudo catalytic scavenger in organophosphate poisoning: a kinetic analysis. Toxicology 259(3):133-139. https://doi.org/10.1016/j.tox.2009.02.014

38. RADIĆ Z, DALE T, KOVARIK Z, BEREND S, GARCIA E, ZHANG L, AMITAI G, GREEN C, RADIĆ B, DUGGAN BM, AJAMI D, REBEK J, TAYLOR P 2013 Catalytic detoxification of nerve agent and pesticide organophosphates by butyrylcholinesterase assisted with nonpyridinium oximes. Biochem J 450:231-242. https://doi.org/10.1042/BJ20121612

39. KATALINIĆ M, MAČEK HRVAT N, BAUMANN K, MORASI PIPERČIĆ S, MAKARIĆ S, TOMIĆ S, JOVIĆ O, HRENAR T, MILIČEVIĆ A, JELIĆ D, ŽUNEC S, PRIMOŽIČ I, KOVARIK Z 2016 A comprehensive evaluation of novel oximes in creation of butyrylcholinesterase-based nerve agent bioscavengers. Toxicol Appl Pharmacol 310: 195-204. https://doi.org/10.1016/j.taap.2016.09.015

40. ZORBAZ T, MALINAK D, KUCA K, MUSILEK K, KOVARIK Z 2019 Butyrylcholinesterase inhibited by nerve agents is efficiently reactivated with chlorinated pyridinium oximes. Chem Biol Interact 307:16-20. https://doi.org/10.1016/j.cbi.2019.04.020

41. WAYMAN JA, GLASSCOCK C, MANSELL TJ, DELISA MP, VARNER JD 2019 Improving designer glycan production in Escherichia coli through model-guided metabolic engineering. Metab Eng Commun 9:e00088. https://doi.org/10.1016/j.mec.2019.e00088

42. DU T, BUENBRAZO N, KELL L, RAHMANI S, SIM L, WITHERS SG, DEFREES S, WAKARCHUK W 2019 A bacterial expression platform for production of therapeutic proteins containing human-like O-linked glycans. Cell Chem Biol 26(2): 203-212.e5. https://doi.org/10.1016/j.chembiol.2018.10.017

43. VALDERRAMA-RINCON JD, FISHER AC, MERRITT JH, FAN YY, READING CA, CHHIBA K, HEISS C, AZADI P, AEBI M, DELISA MP 2012 An engineered eukaryotic protein glycosylation pathway in Escherichia coli. Nat Chem Biol 8(5): 434-436. https://doi.org/10.1038/nchembio.921

44. YANAGISAWA T, SUMIDA T, ISHII R, TAKEMOTO C, YOKOYAMA S 2010 A paralog of lysyl-tRNA synthetase aminoacylates a conserved lysine residue in translation elongation factor P. Nat Struct Mol Biol 17(9): 1136-1143. https://doi.org/10.1038/nsmb.1889 
45. BUSKIRK AR, GREEN R 2013. Getting past polyproline pauses. Science 339(6115):38-39.

https://doi.org/10.1126/science.1233338.

46. QI F, MOTZ M, JUNG K, LASSAKJ, FRISHMAN D 2018 Evolutionary analysis of polyproline motifs in Escherichia coli reveals their regulatory role in translation. PLoS Comput Biol 14(2): 1-19. https://doi.org/10.1371/journal.pcbi.1005987

47. VOLKWEIN W, KRAFCZYK R, JAGTAP PKA, PARR M, MANKINA E, MACOŠEK J, GUO Z, FÜRST MJLJ, PFAB M, FRISHMAN D, HENNIG J, JUNG K, LASSAKJ 2019 Switching the post-translational modification of translation elongation factor EF-P. Front Microbiol 10: 1-16.

https://doi.org/10.3389/fmicb.2019.01148

48. GOLDENZWEIG A, GOLDSMITH M, HILL SE, GERTMAN O, LAURINO P, ASHANI Y, DYM O, UNGER T, ALBECK S, PRILUSKY J, LIEBERMAN RL, AHARONI A, SILMAN I, SUSSMAN JL, TAWFIK DS, FLEISHMAN SJ 2016 Automated structure- and sequence-based design of proteins for high bacterial expression and stability. Mol Cell 63(2): 337-346. https://doi.org/10.1016/j.molcel.2016.06.012

49. NACHON F, NICOLET Y, VIGUIE N, MASSON P, FONTECILLA-CAMPS JC, LOCKRIDGE O 2002 Engineering of a monomeric and low-glycosylated form of human butyrylcholinesterase: expression, purification, characterization and crystallization. Eur J Biochem 269: 630-637.

https://doi.org/10.1046/j.0014-2956.2001.02692.x

50. LOCKRIDGE O, BLONG RM, MASSON P, FROMENT MT, MILLARD CB, BROOMFIELD CA 1997 A single amino acid substitution, Gly117His, confers phosphotriesterase (organophosphorus acid anhydride hydrolase) activity on human butyrylcholinesterase. Biochemistry 36: 786-795.

https://doi.org/10.1021/bi961412g

51. BRAZZOLOTTO X, IGERT A, GUILLON V, SANTONI G, NACHON F 2017 Bacterial expression of human butyrylcholinesterase as a tool for nerve agent bioscavengers development. Molecules 22(11): 1-16. https://doi.org/10.3390/molecules22111828

52. CAI Y, ZHOU S, STEWART MJ, ZHENG F, ZHAN CG 2019 Dimerization of human butyrylcholinesterase expressed in bacterium for development of a thermally stable bioscavenger of organophosphorus compounds. Chem Biol Interact 310:1-7. https://doi.org/10.1016/j.cbi.2019.108756

53. HATAHET F, BOYD D, BECKWITH J 2014 Disulfide bond formation in prokaryotes: history, diversity and design. Biochim Biophys Acta 1844(8):1402-1414. https://doi.org/10.1016/j.bbapap.2014.02.014

54. LOBSTEIN J, EMRICH CA, JEANS C, FAULKNER M, RIGGS P, BERKMEN M 2012 SHuffle, a novel Escherichia coli protein expression strain capable of correctly folding disulfide bonded proteins in its cytoplasm. Microb Cell Fact 11:753.

https://doi.org/10.1186/1475-2859-11-56

55. FATHI-ROUDSARI M, AKHAVIAN-TEHRANI A, MAGHSOUDI N 2016 Comparison of three Escherichia coli strains in recombinant production of reteplase. Avicenna J Med Biotechnol 8(1): $16-22$.

56. CHATONNET A, BRAZZOLOTTO X, HOTELIER T, LENFANT N, MARCHOT P, BOURNE Y 2019 An evolutionary perspective on the first disulfide bond in members of the cholinesterase-carboxylesterase (COesterase) family: possible outcomes for cholinesterase expression in prokaryotes. Chem Biol Interact 308: 179-184. https://doi.org/10.1016/j.cbi.2019.05.016

57. LARSON MA, LOCKRIDGE O, HINRICHS SH 2014 Polyproline promotes tetramerization of recombinant human butyrylcholinesterase. Biochem J 462(2): 329-335. https://doi.org/10.1042/BJ20140421

58. WANG Q, CHEN CH, CHUNG CY, PRIOLA J, CHU JH, TANG J, ULMSCHNEIDER MB, BETENBAUGH MJ 2018 Proline-rich chaperones are compared computationally and experi- mentally for their abilities to facilitate recombinant butyrylcholinesterase tetramerization in CHO Cells. Biotechnol J 13(3): 1-11. https://doi.org/10.1002/biot.201700479

59. DUYSEN EG, BARTELS CF, LOCKRIDGE O 2002 Wild-type and $\mathrm{A} 328 \mathrm{~W}$ mutant human butyrylcholinesterase tetramers expressed in Chinese hamster ovary cells have a 16-hour half-life in the circulation and protect mice from cocaine toxicity. J Pharmacol Exp Ther 302(2): 751-758. https://doi.org/10.1124/jpet.102.033746

60. LI S, IP DTM, LIN HQ, LIU JM, MIAO YG, KE LJ, WAN DCC 2010 High-level expression of functional recombinant human butyrylcholinesterase in silkworm larvae by Bac-to-Bac system. Chem Biol Interact 187(1-3): 101-105. https://doi.org/10.1016/j.cbi.2010.03.055

61. SCHNEIDER JD, CASTILHO A, NEUMANN L, ALTMANN F, LOOS A, KANNAN L, MOR TS, STEINKELLNER H 2014 Expression of human butyrylcholinesterase with an engineered glycosylation profile resembling the plasma-derived orthologue. Biotechnol J 9(4): 501-510. https://doi.org/10.1002/biot.201300229

62. CORBIN JM, HASHIMOTO BI, KARUPPANAN K, KYSER ZR, WU L, ROBERTS BA, NOE AR, RODRIGUEZ RL, MCDONALD KA, NANDI S 2016 Semicontinuous bioreactor production of recombinant butyrylcholinesterase in transgenic rice cell suspension cultures. Front Plant Sci 7: 1-9.

https://doi.org/10.3389/fpls.2016.00412

63. GEYER BC, KANNAN L, CHERNI I, WOODS RR, SOREQ H, MOR TS 2010 Transgenic plants as a source for the bioscavenging enzyme, human butyrylcholinesterase. Plant Biotechnology Journal 8: 873-886.

https://doi.org/10.1111/j.1467-7652.2010.00515.x

64. ALKANAIMSH S, KARUPPANAN K, GUERRERO A, TUAM, HASHIMOTO B, HWANG MS, PHU ML, ARZOLA L, LEBRILLA CB, DANDEKAR AM, FALK B W, NANDI S, RODRIGUEZ RL, MCDONALD KA 2016 Transient expression of tetrameric recombinant human butyrylcholinesterase in Nicotiana benthamiana. Front Plant Sci 7: 1-13.

https://doi.org/10.3389/fpls.2016.00743

65. HUANG YJ, HUANG Y, BALDASSARRE H, WANG B, LAZARIS A, LEDUC M, BILODEAU AS, BELLEMARE A, CÔTÉ $M$, HERSKOVITS P, TOUATI M, TURCOTTE C, VALEANU L, LEMÉE N, WILGUS H, BÉGIN I, BHATIA B, RAO K, NEVEU N, BROCHU E, PIERSON J, HOCKLEY DK, CERASOLI DM, LENZ DE, KARATZAS CN, LANGERMANN S 2007 Recombinant human butyrylcholinesterase from milk of transgenic animals to protect against organophosphate poisoning. Proc Natl Acad Sci USA 104(34): 13603-13608. https://doi.org/10.1073/pnas.0702756104

66. LU D, SHANG S, LIU S, WU Y, WU F, TAN T, LI Q, DAI Y, HU X, ZHAO Y, LI N 2014 Expression of recombinant human butyrylcholinesterase in the milk of transgenic mice. Front Agric Sci Eng 1(3): 179-184. https://doi.org/10.15302/J-FASE-2014020

67. ZHANG P, JAIN P, TSAO C, SINCLAIR A, SUN F, HUNG HC, BAI T, WU K, JIANG S 2016 Butyrylcholinesterase nanocapsule as a long circulating bioscavenger with reduced immune response. J Control Release 230: 73-78. https://doi.org/10.1016/j.jconrel.2016.04.008

68. BRAID LR, WOOD CA, FORD BN 2019 Human umbilical cord perivascular cells: a novel source of the organophosphate antidote butyrylcholinesterase. Chem Biol Interact 305: 66-78. https://doi.org/10.1016/j.cbi.2019.03.022

69. CHILUKURIN, DUYSEN EG, PARIKH K, SUN W, DOCTOR BP, LOCKRIDGE O, SAXENA A 2008 Adenovirus-mediated gene transfer of human butyrylcholinesterase results in persistent high-level transgene expression in vivo. Chem Biol Interact 175: 327-331. https://doi.org/10.1016/j.cbi.2008.04.009

70. CHILUKURI N, DUYSEN EG, PARIKH K, DITARGIANI R, DOCTOR BP, LOCKRIDGE O, SAXENA A 2009 Adenovirustransduced human butyrylcholinesterase in mouse blood functions 
as a bioscavenger of chemical warfare nerve agents. Mol Pharmacol 76(3): 612-617. https://doi.org/10.1124/mol.109.055665

71. PARIKH K, DUYSEN EG, SNOW B, JENSEN NS, MANNE V, LOCKRIDGE O, CHILUKURI N 2011 Gene-delivered butyrylcholinesterase is prophylactic against the toxicity of chemical warfare nerve agents and organophosphorus compounds. J Pharmacol Exp Ther 337(1): 92-101. https://doi.org/10.1124/jpet.110.175646

72. SALMON F, GROSIOS K, PETRY H 2014 Safety profile of recombinant adeno-associated viral vectors: focus on alipogene tiparvovec (Glybera). Expert Rev Clin Pharmacol 7(1): 53-65. https://doi.org/10.1586/17512433.2014.852065

73. MURTHY V, GAO Y, GENG L, LEBRASSEUR NK, WHITE TA, PARKS RJ, BRIMIJOIN S 2014 Physiologic and metabolic safety of butyrylcholinesterase gene therapy in mice. Vaccine 32(33): 4155-4162. https://doi.org/10.1016/j.vaccine.2014.05.067
74. GENG L, GAO Y, CHEN X, HOU S, ZHAN CG, RADIC Z, PARKS RJ, RUSSELL SJ, PHAM L, BRIMIJOIN S 2013 Gene transfer of mutant mouse cholinesterase provides high lifetime expression and reduced cocaine responses with no evident toxicity. PLoS One 8(6): 1-11. https://doi.org/10.1371/journal.pone.0067446

75. GUPTA V, CADIEUX LC, MCMENAMIN D, MEDINAJASZEK CA, ARIF M, AHONKHAI O, WIELECHOWSKI E, TAHERI M, CHE Y, GOODE T, LIMBERIS MP, LI M, CERASOLI DM, TRETIAKOVA AP, WILSON JM 2019 Adeno-associated virus-mediated expression of human butyrylcholinesterase to treat organophosphate poisoning. PLoS One 14(11): e0225188. https://doi.org/10.1371/journal.pone.0225188

76. GAO Y, GENG L, CHEN VP, BRIMIJOIN S 2017 Therapeutic delivery of butyrylcholinesterase by brain-wide viral gene transfer to mice. Molecules 22(7): 1145.

https://doi.org/10.3390/molecules22071145 